JOURNAL OF SECURITY AND SUSTAINABILITY ISSUES

ISSN 2029-7017 print/ISSN 2029-7025 online

2021 Volume 11

https://doi.org/10.47459/jssi.2021.11.26

\title{
SOCIAL SECURITY OF POLAND IN THE XXI CENTURY - THREATS, CHALLENGES, PERSPECTIVES
}

\author{
Jerzy Trocha \\ Academy of Justice, 50 Wiśniowa Street, 02-520 Warsaw, Poland \\ E-mail address: jerzy.trocha@swws.edu.pl
}

Received 13 November 2020; accepted 25 March 2021; published 30 June 2021

\begin{abstract}
The article presents the problem of selected aspects of social security in Poland. A source of motivation to address the issue of social security for the author was the geopolitical situation related to the increase in the number of Muslim immigrants in Europe in recent years and the current COVID-19 epidemic. Counteracting the threats of a social nature has become one of the main activities of the state in the $21^{\text {st }}$ century. Social security relates to a wide range of activities carried out by the public administration, NGOs and the local communities to guarantee decent living conditions. All of this constitutes a special kind of security, the lack of which directly interferes with the foundations of a nation's existence. The aim of the study was to present issues related to the depopulation process affecting Poland and the demographically unfavourable changes taking place in modern families. The article presents the situation prior to the emergence of the COVID-19 epidemic. Undoubtedly, the COVID-19 epidemic will significantly affect social security, also in the demographic dimension. However, the overall impact of the epidemic can only be estimated after it has completely ceased. Conclusions included in the article were formulated on the basis of the analysis of statistical data of the Central Statistical Office. In addition, the author points out the consequences resulting from a long-term demographic collapse in the country.
\end{abstract}

Key words: security, national security, social security, demography, society, migration, family

Reference to this paper should be made as follows: Trocha, J. 2021. Social security of Poland in the XXI century - threats, challenges, perspectives. Journal of Security and Sustainability Issues, 11, 301-312. https://doi.org/10.47459/jssi.2021.11.26

Additional disciplines: security, COVID-19

\section{Introduction}

Security has been an integral part of human life for centuries. Striving to maintain its acceptable level in all areas of human existence has invariably been one of the main objectives of all societies. The desire for security is an elementary human need ${ }^{1}$ which determines progress. Over the years, the way it is perceived has evolved. The development of civilisation has led to progress in many areas of life, and as a consequence has also generated new threats. The identification of security solely in terms of military potential has proved to be too narrow a definition. In fact, dangers resulting from social, economic, commercial and cultural factors affecting both the individual and society as a whole have been recognised.

The multidimensionality of security requires continuous scientific research. Currently, as a result of empirical knowledge of national security, its military, political, economic, environmental, cultural, social, public and universal aspects may be distinguished. In reviewing the problems of security, the author focused his research interests on security in the social dimension. This concept is defined as the protection of the existential basis of people's lives, ensuring the satisfaction of individual needs (material and spiritual), the realisation of life

1 Vide, A. Maslow, Motywacja i osobowość [Motivation and personality], PWN, Warszawa 2006, p. 62. 
aspirations through the creation of conditions for work and study, health protection and pension guarantees ${ }^{2}$.

Social security pertains to a wide range of activities carried out by public administration, non-governmental organisations and the local community to guarantee decent living conditions. It represents a special kind of security, the lack of which directly interferes with the foundations of the nation's existence. A proper social policy of the authorities identified with this category of national security is connected with activities of a legal, educational and organisational nature. The multitude of social security problems places it among the most important activities of the state in the $21^{\text {st }}$ century. It embraces the spheres of deprivation and poverty, social pathologies, unemployment and demographic aspects.

In recent years, the world media have been dominated by reports of Muslim migration from Syria to Europe. High living standards and social benefits for the unemployed have made the developed countries of the European Union an attractive destination for refugees. The sizeable migrant population has exposed the EU's unpreparedness for the circumstances. The growth of the illegal Muslim population in Europe has led to social conflicts between supporters and opponents of immigrant admission. The resulting situation is of interest not only to demographers but also to social security researchers. The different family model favouring procreation, or concerns about the lack of assimilation of the migrant population into European social life patterns, have been aggravated by the negative experiences of Germany and France in this respect.

At present, however, the world is facing a pandemic of the infectious respiratory disease COVID-19 caused by the SARS-CoV-2 virus transmission. The disease has contributed to the deaths of more than 2 million people ${ }^{3}$ thus leading to a global economic crisis. The fight against the epidemic determined almost the entire year 2020. The efforts to reduce the number of infections and deaths had an impact on all areas of social life, both public and private. Extensive restrictions, orders and bans as well as other limitations introduced by the authorities of the countries affected by the epidemic led to tremendous losses in various sectors of the economy. Undoubtedly, the COVID-19 epidemic has had a significant impact on social security, not least in the demographic dimension. However, the full impact of the epidemic can only be estimated once the threat has been completely eliminated.

The events described illustrate the multifaceted nature of social security problems. This compels reflection on the social security of one's own country. The present study is a review publication of selected aspects related to the issue of Poland's social security in the $21^{\text {st }}$ century from the period preceding the COVID-19 epidemic.

\section{Social threats}

The modern perception of civil protection is not limited to natural or military hazards. Therefore, hazards of a social nature are an essential element of any state. On the basis of the knowledge gathered, these threats are divided into social and psycho-social ${ }^{4}$.

The threats arising from the psychosocial sphere are defined as a state of society exhibiting such an intensity of negative influences and phenomena as a result of which the existential values and interests of the nation and the state are shaken and a possibility of degradation of public awareness exists ${ }^{5}$. It includes threats related to: religious extremism, chauvinism and xenophobia, discrimination and social exclusion, failure to respect human rights, importation of foreign culture, manipulation of public opinion by the mass media or brutalisation of social relations. The term social threats, on the other hand, is associated with the sphere of poverty and deprivation.

\footnotetext{
2 A. Skrabacz, Bezpieczeństwo społeczne. Podstawy teoretyczne i praktyczne [Social Security. Theoretical and practical foundations], Dom Wydawniczy ELIPSA, Warsaw 2012, p. 9.

3 https://www.worldometers.info/coronavirus/ [access date: 02.03.2021].

4 Vide, A. Skrabacz, Uwarunkowania tworzenia bezpieczeństwa spolecznego w XXI wieku [The conditions for establishing social security in the 21st century], in: A. Skrabacz, S. Sulowski (eds.), Bezpieczeństwo społeczne. Pojęcie, uwarunkowania, wyzwania [Social security. Concept, determinants, challenges], Dom Wydawniczy ELPISA, Warsaw 2012, p. 53.

5 Stownik terminów z zakresu bezpieczeństwa narodowego [The glossary of terms in the field of national security], AON, Warsaw 2002, p. 87.
} 
It is influenced by: high unemployment rate, lack of perspectives for decent work, shortage of funds for supporting the family and dwelling as well as gradual lowering of living conditions of the population.

The threats listed above do not exhaust the scope of hazards that should be classified under social threats. Other important factors reducing the level of social security are demographic problems and pathological behaviours. The dangers resulting from an unfavourable demographic trend relate to all nations, as they impinge on the foundations of their existence. For this reason, the activities of state authorities in this area are of a universal nature. Population growth and migration are the most important elements of the risks arising from demographic aspects. The resulting consequences could lead to the depopulation of a country.

Birth rate is defined as the difference between the number of live births and the total number of deaths. Demographers distinguish two trends to explain this phenomenon. The first concerns the need for biological survival, which is characterised by high birth and death rates. It is dominant in poor societies in undeveloped countries. The second trend focuses on reducing mortality. It aims to maintain a balance between deaths and births. It exists in developed countries, where, as a result of advanced medicine and pharmacology, human life expectancy is increasing. With advances in technology, society is experiencing a demographic shift from the first trend to the second. As a result, there is a decline in both deaths and births. This poses a major problem for some European Union countries. The low birth rate that has become a hallmark of developed countries is one of the key threats to civilisation in the $21^{\text {st }}$ century. Demographers prognosticate that despite the increase in life expectancy in Western European countries, the total number of citizens in these countries will decrease dramatically by 2050 . The global birth rate for 2018 was at a level of $1.11 \%{ }^{6}$.

A threat influencing the low birth rate, unaddressed in many publications on the subject, yet having a significant impact on demographic aspects of social security, is the unfavourable evolution of the family model. Over the years, the family has invariably been the elementary cell ensuring the biological survival of a nation. Multichild marital union between a man and a woman was the basis of the traditional family. The main reason for the high fertility rate among the population was the high death rate among children in the first years of life. The underdeveloped medicine of the time did not allow for the treatment of a number of childhood illnesses that today are no longer a threat to health and life. Another important factor influencing family size was the tangible benefits for all family members. For parents, it was a guarantee that their children would be cared for in their old age, whereas for children, the family served economic, social and educational functions. Over time, as a result of the introduction of the pension system, high taxes, the development of medicine and pharmacology, and the socio-cultural trends of various ideologies, the family model, beneficial from the point of view of national security, has undergone modifications. However, the role of the family as the foundation of the nation's existence has not changed. Financial reasons and the pursuit of professional careers for both spouses have reduced female fertility, thus creating a new family pattern, the so-called " $2+1$ " (parents and one child).

Another important demographic aspect in terms of social risks is migration. At the end of the $20^{\text {th }}$ century, as a result of political changes in Central and Eastern Europe, the territorial mobility of society increased. The rate of international travel is particularly high in the European Union, where almost all countries belong to the Schengen area. The possibility of passport-free travel in the Member States has led to an increase in the number of temporary and permanent migrations of people in all Member States.

Emigration particularly concerns the new EU countries, which are experiencing an exodus of people to the countries of the 'old' Union on account of their greater opportunities for development. Deficiencies in education and an inefficient economy leading to unemployment force some of the population to travel abroad for work. Lack of professional development opportunities and low wages that do not allow the family to support itself contribute to the desire to leave the country. From an economic point of view, an increase in the outgoing population has a negative impact on the state's economy. It slows down technological progress, lowers the value of the GDP and reduces tax revenues to the state budget. Permanent emigration is particularly dangerous

6 World Bank, http://www.google.com/publicdata/explore?ds=d5bncppjof8f9_\&ctype=l\&strail=false\&nselm=h\&met_y=sp_pop_ grow\&met_y=sp_pop_grow [access date: 02.03.2021]. 
from the point of view of national security. There is a risk that during the assimilation process society will lose its national values. Moreover, it is likely that the children of emigrants, born, raised and educated abroad, will not identify with their country of origin. The support and education of parents in this area is therefore essential for the development of a new generation abroad.

Another social threat consists in pathological behaviours. The term pathology, from the Greek pathos, is defined as (...) the totality of cases of death, lowering of the moral level, deterioration of well-being and material losses caused by violation of praxeological, moral and legal rules and self-destructive behaviour ${ }^{7}$. The problem of pathology is closely related to the negative consequences of cultural, economic and political factors affecting social groups. The most frequent examples of social pathologies are: prostitution, crime, domestic violence, alcoholism and drug addiction.

The threat of pathology is a specific problem for all communities. This stems from the principle of negative synergy which is their feature. In light of this, pathological phenomena spread into larger communities. The population affected by pathology inevitably absorbs other social groups, thus leading to dangerous consequences for the state. It is therefore extremely important to create appropriate conditions for society to counteract individual cases of pathology.

\section{Legal regulation of the social security of the Republic of Poland}

Reducing the risk of threats of a social nature requires the necessary legal measures. They constitute elementary standards regulating the life of citizens in every civilised state. Law on social security should be discerned in respect of its international and national dimensions.

Supranational regulations are created primarily at the initiative of the United Nations. As a result of the work of the United Nations during the 1966 conference, the International Covenant on Civil and Political Rights was adopted by 168 states through General Assembly resolutions. It constitutes the most important global source of legal norms. It defines human freedoms and rights, protection of the family and the disabled and workers, as well as the principles of work organisation. In turn, legal determinants of the issue of social security of the Republic of Poland are contained in constitutional, civil, labour, administrative, economic (public and private), family, criminal and procedural law ${ }^{8}$.

The support provided by the state to citizens assumes different forms. National law specifies the scope of social assistance, social benefits, housing allowances, assistance to families and children and care for the disabled. In addition, it is designed to protect labour, promote employment and social insurance. The problem of financial support concerns the unemployed, families with children and single persons bringing up children and not receiving child support payments. State intervention aimed at helping the family is also associated with the prevention of violence, the realization of "Large Family Card" programmes, nutrition in schools for children from poor families and the payment of social benefits 9 .

A particularly important element is assistance to families affected by violence. Social welfare homes, homes for single mothers with a minor child and homes for pregnant women are operated throughout the country. Individuals affected by domestic violence can seek shelter in such facilities free of charge. State aid is also provided for children without legal guardians. They are looked after by workers of adoption and care centres.

The activities of state bodies also include assistance to people with disabilities. The main normative act grant-

\footnotetext{
7 J. Malec, Patologia społeczna jako zjawisko. Projekt definicji [Social pathology as a phenomenon. Definition proposal], Państwo i prawo 1986, no. 4, p. 17.

8 Vide, W. Kilter, Bezpieczeństwo narodowe RP. Podstawowe kategorie, uwarunkowania, system, AON, Warsaw 2011 , p. 168.

9 Vide, ibidem, p. 171.
} 
ing (...) the right to independent, autonomous and active life ${ }^{10}$ to people with disabilities is the Charter of Rights of Persons with Disabilities. The document, adopted by the Resolution of the Sejm of the Republic of Poland on 1 August 1997, is intended to activate the disabled to participate in public and professional life and protect them against social exclusion. In addition, a number of campaigns for people with disabilities are regularly held in the country to raise awareness among employers about their high qualifications and competences. The aim of the campaigns is to show that physical disability does not affect a disabled person's fitness for work.

\section{Challenges for the social security of Poland}

The vital importance of social threats to national security is indisputable. The multitude of problems faced by the Republic of Poland, underpinned by social threats, makes this an exceptionally wide-ranging issue. In view of the foregoing and limitations in terms of volume, this paper analyses only selected aspects of Poland's social security. In the author's opinion, their counteraction is the key challenge for the state in the $21^{\text {st }}$ century.

\section{Demographic aspects}

Since the late 1990s Poland has been affected by the process of depopulation. As in other EU countries, the risks of a dangerous demographic decline have become a real concern for the future. The consequences of this state of affairs may have a negative impact on the national economy through the limitation of the GDP development, increase in unemployment or inefficiency of the public finance system. The economic instability of society has resulted in a change in the approach to procreation. Poland's entry into a phase of demographic collapse is reflected in Figure 1, which shows the population change in the country over the period between 1990-2019.

Figure 1. Natural population movement and the migration rates in the period 1990-2019

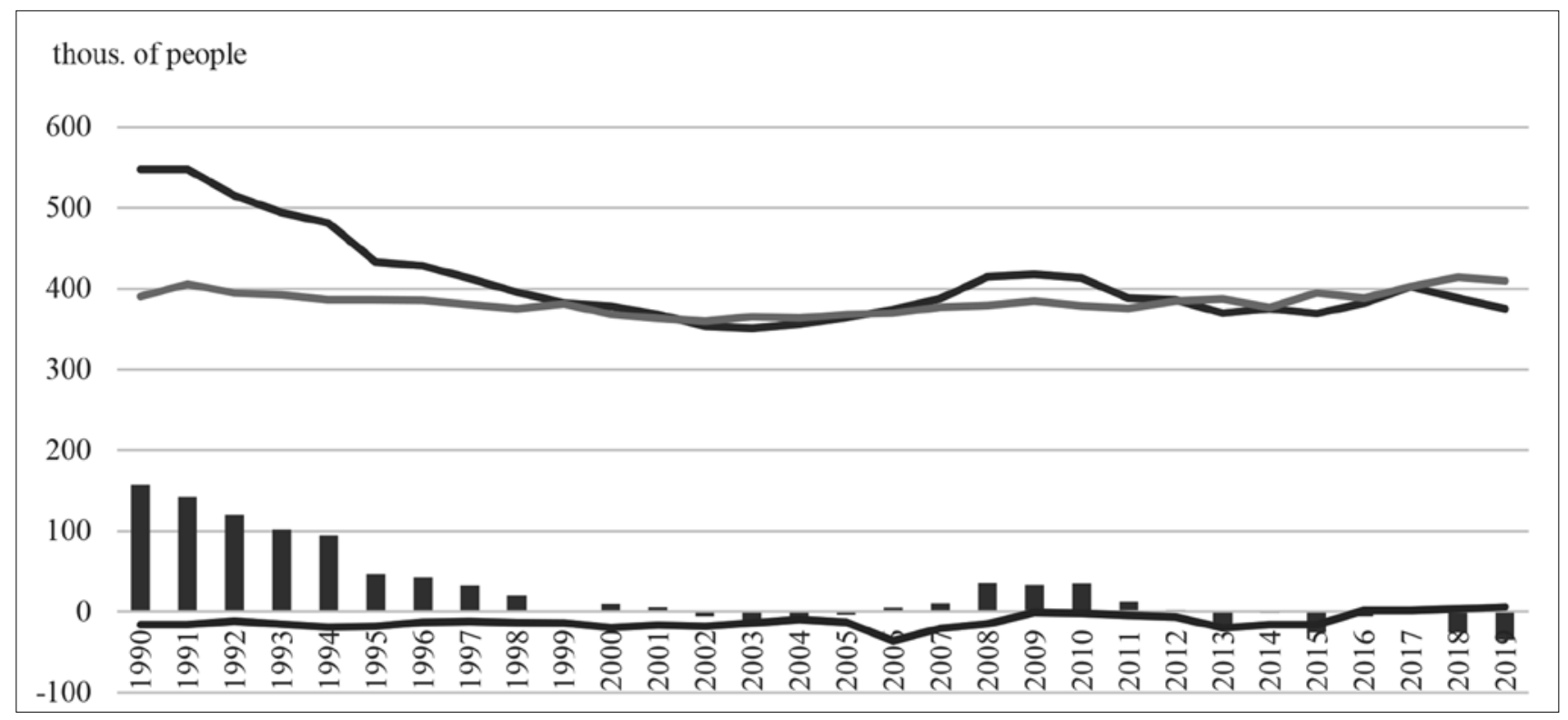

Legend: blue - birth rate; red - live births; green - deaths; violet - migration rate

Source: own elaboration based on Rocznik demograficzny 2020 [Demographic Yearbook 2020], Central Statistical Office (GUS), Warsaw 2020, pp. 26-27.

As evidenced by the data, a gradual decrease in birth rates took place in the 1990s, until 1999, when, as a result of the number of live births equalling the total number of deaths, it reached zero for the first time since the end of World War II. In the following years its slight modifications were observed, but between 2002 and 2005 an

${ }^{10}$ Uchwata Sejmu Rzeczypospolitej Polskiej z dnia 1 sierpnia 1997 r. - Karta Osób Niepetnosprawnych [Resolution of the Sejm of the Republic of Poland of 1 August 1997 - Charter of Disabled Persons], M.P. [Monitor Polski] of 1997 no. 50 it. 475, Sec.1 
alarming negative natural growth was recorded. The danger of a reduction of the development potential of the state from this situation became considerable, as it created the risk of decrease in labour supply. In the following years, the slight increase in the birth rate did not translate into a steady upward trend. In 2011, a successive decline was once again observed, while from 2013 to 2019, the number of deaths was again higher than live births. In 2019, the lowest natural growth rate in the period under review was recorded, amounting to -34.8 . The presented data show that Poland, along with the progress of civilization, has undergone a demographic transition, as a result of which a relative balance between the number of live births and deaths has been maintained. However, the years 2017-2019 reveal a dangerous trend related to the decreasing negative birth rate. It can be assumed that in 2020 the problem will worsen due to the COVID-19 pandemic, as the epidemic contributes to an increase in the number of deaths, and may also indirectly affect the decrease in the number of live births, assuming that the population will postpone the decision to have children owing to fear of the difficult situation of health services during the pandemic. The unfavourable situation related to the natural growth is a result of a decrease in fertility of women of reproductive age (15-49 years). The gradual decline in the ratio between 1990 and 2019 is shown in Figure 2.

Figure 2. Fertility rate of women in 1990-2019

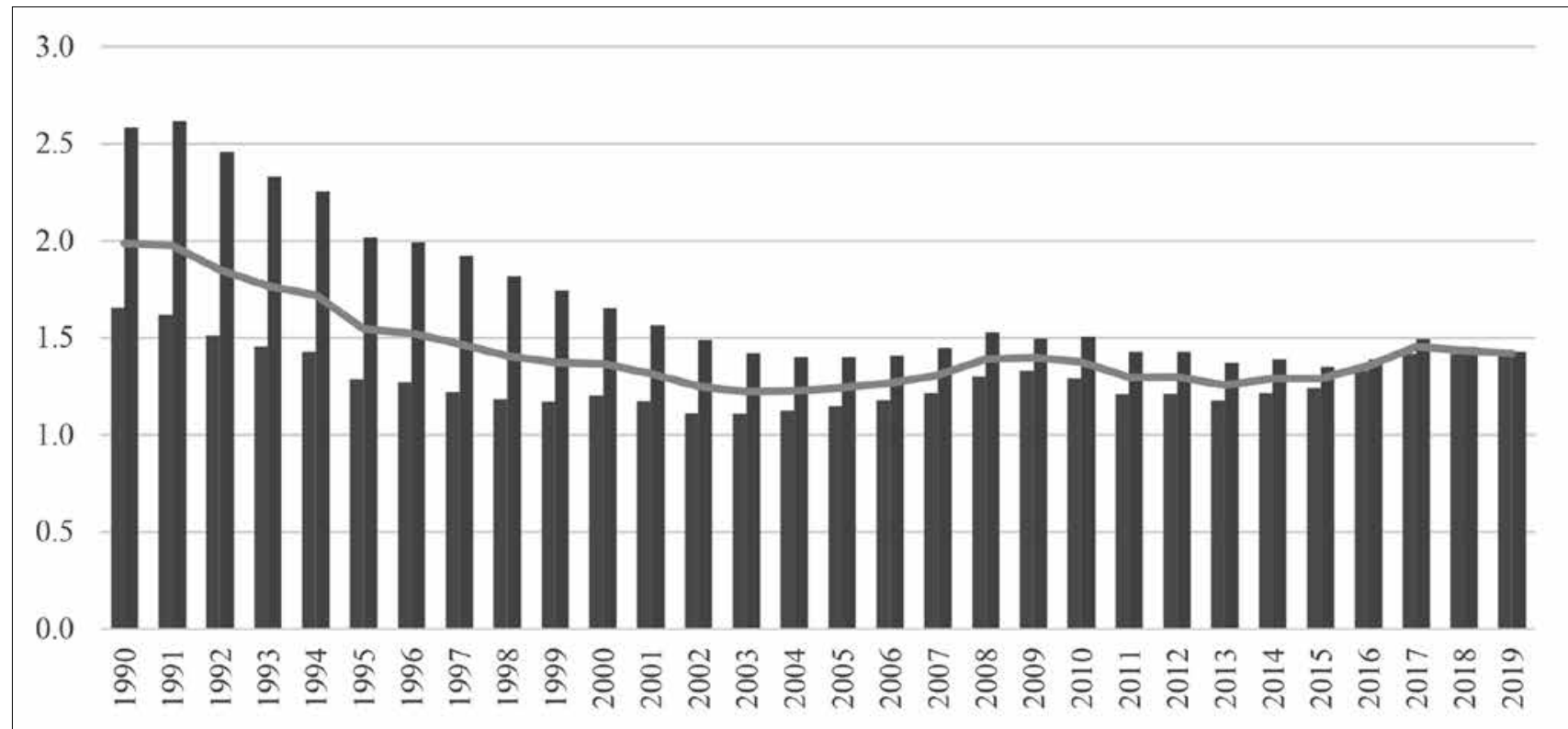

Legend: blue - urban areas; red - rural areas; green - total

Source: own elaboration based on Rocznik demograficzny 2020 [Demographic Yearbook 2020],

Central Statistical Office (GUS), Warsaw 2020, pp. 50-51, 287.

Since the early 1990s, the fertility rate has gradually decreased. The downward trend has led to a convergence of the urban and rural rates. The conviction prevailing in society that the fertility of women in the countryside is higher seems outdated in view of the data presented. In 1990, the total number of children born per woman was a value of 2, while in 2019 it dropped to 1.4. The data from the statistics of the Central Statistical Office are alarming. Despite a slight increase in female fertility between 2014 and 2017, the demographic situation of the country has not improved and the birth rate has not exceeded zero. According to demographic analyses, between 2000 and 2060, if the fertility rate remains at its current level, the population of Poland will fall to approximately 29.2-32 million ${ }^{11}$. The above situation, being a consequence of unfavourable changes in the approach to procreation in the future, threatens the natural succession of generations. Demographers predict that it will be necessary to return to the old trends of two children being born per woman ${ }^{12}$.

Foreign migration is another demographic aspect affecting social security. Its size is influenced by the level of

\footnotetext{
11 Vide, M. Leszczyński, Wpływ demografii na poziom bezpieczeństwa społecznego, in: A. Skrabacz., S. Sulowski (eds.), Bezpieczeństwo społeczne. Pojęcie, uwarunkowania, wyzwania [Social security. Concept, determinants, challenges], Dom Wydawniczy ELIPSA, Warsaw 2012, p. 183.

12 Vide, P. Eberhardt, Mato nas [There are few of us], Rzeczpospolita of 21.12.1999.
} 
unemployment and the level of remuneration for work in the home country, as well as the possibility of passportfree travel in the Schengen countries. Long-term absence in the domestic labour market increases the willingness of the population to travel abroad for work. This thesis is reflected in statistical data. The unemployment rate registered in Poland in 2003 was about 19\%, but after the country joined the European Union in the following years its value dropped dramatically. Currently it amounts to $5.5 \%{ }^{13}$. The outflow of the unemployed population from the country to the developed EU countries has definitely contributed to this trend. Despite the fact that the unemployment rate does not reflect the real scale of the phenomenon, because statistical records include only persons registered in labour offices, it must be stated with all certainty that Poland's accession to the EU has seemingly improved the situation on the national labour market. It should, however, be remembered that economic emigration of well-educated citizens is also a loss for the state. Education and skills acquired by them in the country will not be used for the benefit of the national economy, which in turn may limit its growth rate.

Changes in the number of permanent and temporary emigrants from Poland in the last 30 years were also related to political events. The systemic transformation in 1989 and the above-mentioned accession to the EU in 2004 enabled citizens to travel freely. Detailed information on the scale of temporary emigration in the years 2002-2019 is presented in Table 1.

Table 1. Emigration from Poland for temporary residence 2002-2019

\begin{tabular}{|c|c|c|c|c|c|c|c|c|c|c|c|c|c|c|c|c|c|}
\hline \multirow[b]{2}{*}{$\begin{array}{l}\text { Place } \\
\text { of stay }\end{array}$} & \multicolumn{17}{|c|}{ Number of emigrants in thousands } \\
\hline & 只 ํํㅇ & ষ্ণ & $\stackrel{\overbrace{}}{8}$ & ঃ̊ & 옹 & $\stackrel{\infty}{\circ}$ & ஓे & $\frac{0}{\circ}$ & $\vec{\nabla}$ & 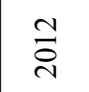 & $\frac{m}{\stackrel{n}{2}}$ & $\stackrel{ \pm}{\stackrel{\Delta}{d}}$ & $\frac{n}{i}$ & $\stackrel{0}{\circ}$ & 공 & $\frac{\infty}{\stackrel{i}{i}}$ & $\frac{a}{\text { ก }}$ \\
\hline Total & 786 & 1000 & 1450 & 1950 & 2270 & 2210 & 2100 & 2000 & 2060 & 2130 & 2196 & 2320 & 2397 & 2515 & 2540 & 2455 & 2415 \\
\hline Europe & 461 & 770 & 1200 & 1610 & 1925 & 1887 & 1765 & 1685 & 1754 & 1816 & 1891 & 2013 & 2098 & 2214 & 2241 & 2155 & 2134 \\
\hline $\begin{array}{c}\text { European } \\
\text { Union } \\
\text { (27 states) }^{\mathrm{c}}\end{array}$ & 451 & 750 & 1170 & 1550 & 1860 & 1820 & 1690 & 1607 & 1670 & 1720 & 1789 & 1901 & 1983 & 2096 & 2121 & 2031 & 2008 \\
\hline $\begin{array}{r}a-\text { Data ref } \\
b-\quad \text { After est } \\
547 \text { thou }\end{array}$ & $r$ to the & number & of perso & ns stayi & $\begin{array}{l}\text { g abro } \\
\text { of und } \\
\text { sand }\end{array}$ & $d$ temp & $\begin{array}{l}\text { rarily: } f \\
\text { d countr. }\end{array}$ & $\begin{array}{l}\text { or } 2002 \\
y \text { of tem }\end{array}$ & $\begin{array}{l}-2006- \\
\text { porary }\end{array}$ & $\begin{array}{l}\text { more tha } \\
\text { tay, the }\end{array}$ & $\begin{array}{l}\text { in } 2 \mathrm{mor} \\
\text { number }\end{array}$ & $\begin{array}{l}\text { ths, for } \\
\text { of emi }\end{array}$ & $\begin{array}{l}2007-20 \\
\text { rants st }\end{array}$ & $\begin{array}{l}19-m o \\
\text { aying in }\end{array}$ & $\begin{array}{l}\text { re than } \\
\text { Europe }\end{array}$ & $\begin{array}{l}3 \text { month } \\
\text { an coun }\end{array}$ & tries is \\
\hline$c-$ Until 20 & $625 \mathrm{stat}$ & & & & & & & & & & & & & & & & \\
\hline
\end{tabular}

Source: own elaboration based on: Informacja o rozmiarach i kierunkach czasowej emigracji z Polski w latach 2004-2019 [Information on the size and directions of temporary emigration from Poland in the years 2004-2019], Central Statistical Office (GUS), Warsaw 2020 p. 2.

As from 2004, the number of emigrants started to sharply increase. The data shows that in 2002 the number of people temporarily leaving the country reached 786,000, while since 2007 the value remained at the level of over 2 million citizens. It is also worth noting that the number of emigrations to EU countries increased. Before Poland's accession to the EU, EU Member States were the destination of emigration for more than half of the citizens, while currently almost $83 \%$ of all temporary emigrants. The presented data confirm the thesis presented in the previous part of the study that the EU membership increased the outflow of population. This is due to the attractiveness of the Community countries for emigrants in terms of their proximity to Poland, similar culture, better earning opportunities and freedom of movement in the Schengen area.

All temporary migrations abroad also carry the risk of transforming into permanent emigration. The financial gains received, a higher standard of living and the need to constantly travel to Poland make some people decide to relocate abroad with their families. Data on permanent emigration in the years 2000-2019 are presented in Figure 3.

\footnotetext{
13 Główny Urząd Statystyczny, https://stat.gov.pl/obszary-tematyczne/rynek-pracy/bezrobocie-rejestrowane/stopa-bezrobocia-rejestrowanego-w-latach-1990-2020,4,1.html [access date: 26.02.2020].
} 


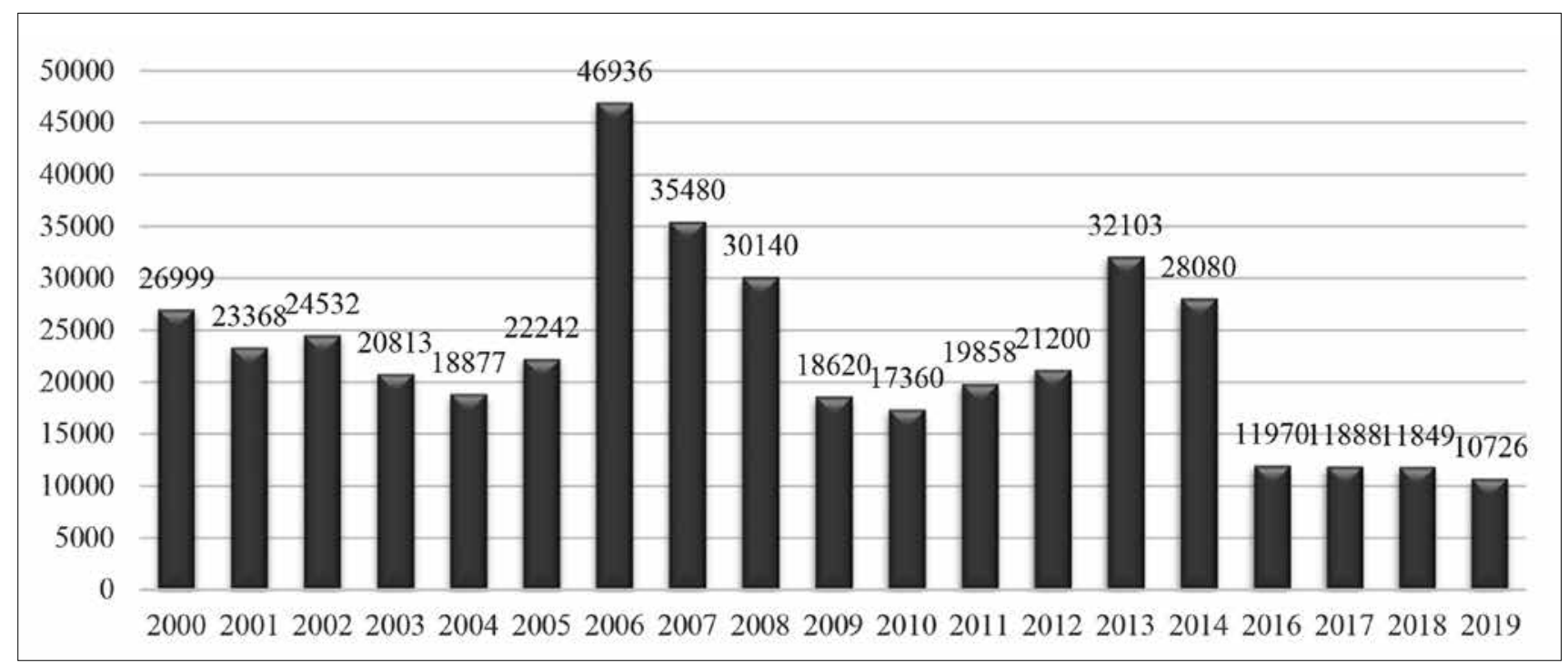

Figure 3. International migration of Poles for permanent residence

Note: lack of data for 2015.

Source: own elaboration based on Sytuacja demograficzna Polski do 2019 r. Migracje zagraniczne ludności w latach 2000-2019 [Demographic situation of Poland until 2019. International migration of population between 2000 and 2019], Central Statistical Office (GUS), Warsaw 2020, p. 220.

In the light of the information presented in the overview for the years 2000-2004 it should be observed that the number of permanent emigration of Poles abroad decreased. The number of emigrants began to significantly increase after Poland's accession to the EU until 2006, when it reached its highest level in the analysed period totalling 46936 people. In the following years, the number of emigrants leaving for permanent residence declined once again. In the period from 2016 to 2019, it amounted to less than 12 thousand emigrants per year. The decrease in the number of citizens leaving the country for permanent residence is a positive development. This is a result of the improvement in the economic conditions of families as a direct consequence of new social programmes to support the family, established in 2016. Despite the lower number of people leaving the country in recent years, it should be noted that since Poland's accession to the EU, more than 337,000 citizens left the country for permanent residence ${ }^{14}$.

In the presence of indisputable facts, fear for Poland's national security is justified. Permanent emigration abroad, lack of contact with the mother country and assimilation to a new place of residence create the risk of losing the bond with the nation. Weakening of the national identity of parents may translate into offspring born and brought up abroad, who without the propagation of Polish culture will not identify with Polish society. Therefore, further economic development of the country and, as a consequence, blurring of differences in the standard of living between Poles and citizens of the 'old' EU countries, is a recipe for lowering the number of people leaving the country for permanent residence in the years to come. When analysing the phenomenon of permanent emigration, research interests are also aroused by the places of foreign migration of population. These are presented in Figure 4.

\footnotetext{
14 Between 2004 and 2019, 337,329 people emigrated from Poland for permanent residence abroad.
} 
Figure 4. International migration directions of Poles for permanent residence

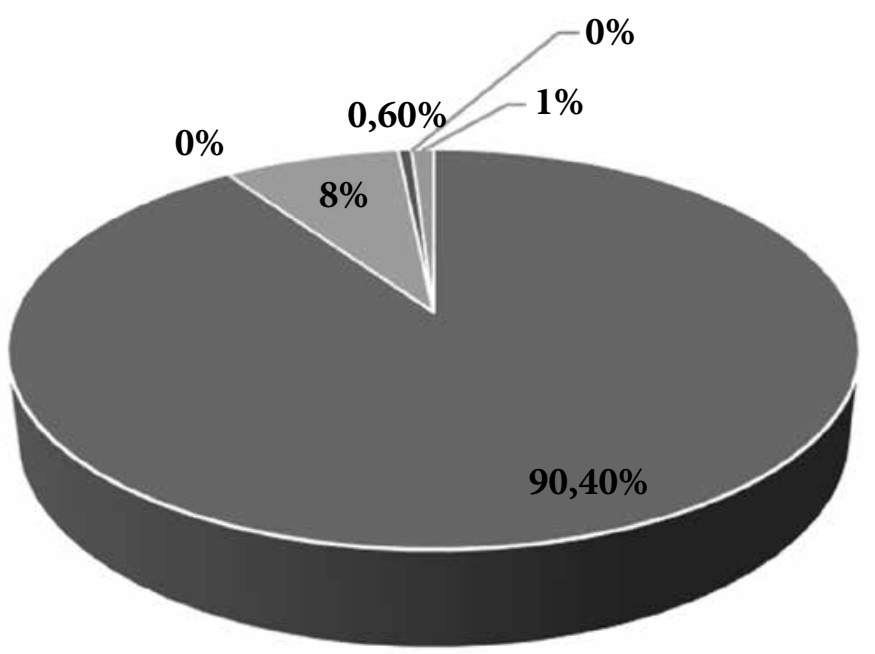

- Europe

- South America

" North and Latin America

- Asia

" Africa

- Australia and Oceania

Source: own elaboration on the basis of Sytuacja demograficzna Polski do 2019 r. Migracje zagraniczne ludności w latach 2000-2019 [Demographic situation of Poland until 2019.

International migration of population between 2000 and 2019], Central Statistical Office (GUS), Warsaw 2020, p. 79.

The pie chart indicates that over $90 \%$ of all permanent emigrants move to other European countries. The above data are consistent with the directions of temporary emigration of Poles. This indicates that the thesis of temporary emigration transforming into permanent one is well founded.

\section{Family evolution in Poland}

Unfavourable changes in the birth and fertility rate have a key impact on the ongoing process of demographic collapse in Poland. It is inextricably linked to the current disintegration of the family. The gradual decline in the female fertility rate began in 1992 . The political changes in the country and the uncertain economic situation resulted in a reduction in the number of births. The state social programmes of the time aimed at helping families did not succeed in raising the fertility rate, which was the result of a lack of strategic consideration of the long-term effects of the programmes introduced.

The decline in the number of live births is primarily determined by economic issues. The costs of having a child are a major obstacle for young people wishing to start a family. The pursuit of a good financial situation has therefore become a priority for both partners. Faced with the pursuit of a professional career, the postponement of starting a family has led to a reduction in fertility rates. It should also be borne in mind that the biological capacity for procreation of adult women decreases with age. Delaying the decision about having children has contributed to a crisis in the traditional approach to the family. Statistics on marriages and divorces are shown in Figure 5 below. 
Figure 5. Number of contracted marriages and divorces in years 990-2019

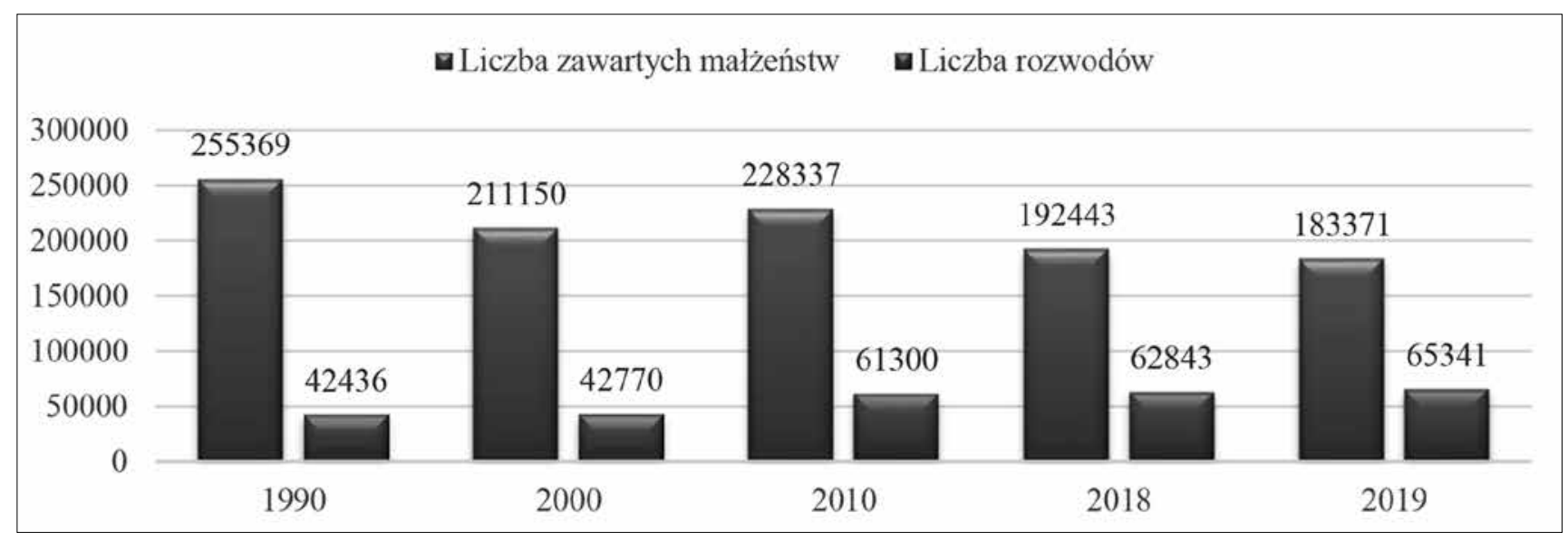

Legend: blue - Number of contracted marriages; red - number of divorces

Source: own elaboration based on Rocznik demograficzny 2020 [Demographic Yearbook], Central Statistical Office (GUS), Warsaw 2020, pp. 181, 230.

The chart shows that the number of marriages contracted has decreased, while the number of divorces has increased. In 2019, the number of marriages contracted decreased by nearly 72,000 compared to 1990 . The reverse is true for divorces, which increased by nearly 23,000 in 2019 compared to 1990. The statistics quoted confirm that the traditional family is undergoing a period of change, resulting from the society's reluctance to establish it. The most frequent motivations for divorce in Poland are extramarital relationships, alcoholism and the incompatibility of the spouses' characters ${ }^{15}$. In addition, socio-economic factors resulting from the need to travel for work have contributed to the family crisis. Economic separation has led to the emergence of the phenomenon of 'euro-orphanhood', whereby a parent or parents leaving to work leave a child in the care of a spouse, grandparents or other relatives. This weakens the special bond between families, which also contributes to the break-up process. Owing to unfavourable economic conditions, the impact of socio-cultural factors on the family has increased. A modification of the approach to procreation, marriage and gender roles has led to the development of alternative family forms. Currently, apart from the traditional family, the following should be distinguished: cohabitation relationships, homosexual relationships, childless marriages, single parenthoods, foster and reconstructed families ${ }^{16}$. The factors influencing the transformation of the modern family include:

- Development of women's educational opportunities and women's professional activation;

- Conflicting gender roles in family relations;

- Changes in the reproduction process of the population (development of medicine and pharmacology enabling fertility control);

- The spread of individualism;

- The conflict between the individual's desire to realise his or her own self and the need to be in permanent and lasting relationships with other people;

- The nature of the relationship between the state, the market and the family in meeting the needs of the individual ${ }^{17}$.

\footnotetext{
15 Notatka informacyjna - Podstawowe informacje o rozwoju demograficznym Polski do 2014 r. [Information note - Basic information on the demographic development of Poland up to 2014], Central Statistical Office (GUS), Warsaw 2015, pp. 9-10.

16 Vide, G. Firlit-Fesnak, Rodziny polskie i polityka rodzinna, stan i kierunki przemian [Polish families and family policy, state and trends of changes], in: G. Firlit-Fesnak (ed.), Polityka społeczna, PWN, Warszawa 2007, p. 188.

17 Ibidem, pp. 189-190.
} 
The influence of these socio-cultural aspects has led to a tendency for society to become increasingly selfdependent. A key issue is the way in which state social policy is conducted. The orientation of the authorities' activities towards family support cannot limit the social, economic and educational functions of the family, as this would consequently weaken family relations between its members. The aim of the state's social policy should be to highlight the benefits of the family for individuals. In the face of the above, it is reasonable to pose the question as to how the state should assist the family in order to contribute to the increase of procreation while not limiting the functions of the family in relation to its members? The answer to the question is not simple, however it is the key to improving the demographic situation in Poland.

At present, three family models exist in the country, which differ according to the function of the spouses. These include:

- the traditional family model (the upkeep of the family is the responsibility of the working man, while the woman is solely responsible for running the home and bringing up the children);

- a family model with a double burden for women (both spouses work gainfully for the household, but the woman is additionally responsible for housekeeping and childcare);

- a family model based on partnership (responsibilities related to maintaining the family, running the home and raising children are divided between both partners).

\section{Conclusions}

To summarise, ensuring the existence of the state in the international arena is the main goal of society beyond all divisions and is inextricably linked with guaranteeing social security for citizens. Concern for the biological survival of the nation and ensuring decent living conditions is also linked with security in the political and economic spheres. The analysis of social threats to Poland leads to the conclusion that the activities of the state in this regard have not yet produced the desired result. In recent years some positive demographic phenomena can be observed, however, despite the general increase in the fertility rate of women and a decrease in the number of permanent emigrants from the country, Poland continues to be threatened by the phenomenon of depopulation on account of a higher number of deaths than live births, as well as an upward trend in temporary emigration. The maintenance of the birth rate and the female fertility rate at the current level will result in the depopulation of the country.

Efforts should be made to further enhance the role of the family in guaranteeing economic and social security for individuals in society. Until recently the benefits of having a family had been unattractive for the society, which resulted in limiting the number of marriages and births of children. For improvement of the above state of affairs, it is necessary to pursue a proper policy aimed at creating good conditions for the population to start a family and raise offspring.

The source of motivation to address the issue of social security for the author was the geopolitical situation related to the increase in the number of Muslim immigrants in Europe in recent years and the current COVID-19 epidemic. The escalation of the conflict in the Middle East contributes to the desire to flee the area affected by the war. Although Poland is presently not threatened by the influx of immigrants from underdeveloped countries, the problem may also affect the Republic of Poland in the future. In particular, the national economy after the COVID-19 epidemic will need to be rebuilt, and therefore the demand for workers may be very high. Another aspect is the impact of epidemics on the areas of deprivation and poverty, social pathologies, unemployment and demography. Therefore, social security activities should constitute a special element of the functioning of the state, as they affect many other areas of life. The dangers arising from social threats impinge on the elementary foundations of a nation's existence. Therefore we should look forward to further data from the Central Statistical Office upon which conclusions can be drawn and social programmes developed. 


\section{References}

Eberhardt P. (1999), Mało nas [There are few of us], Rzeczpospolita of 21.12.1999.

Firlit-Fesnak G. (2007), Rodziny polskie i polityka rodzinna, stan i kierunki przemian [Polish families and family policy, state and trends of changes], in: G. Firlit-Fesnak (ed.), Polityka społeczna, PWN, Warsaw, p. 188.

Informacja o rozmiarach i kierunkach czasowej emigracji z Polski w latach 2004-2019 (2020) [Information on the size and directions of temporary emigration from Poland in the years 2004-2019 (2020)], Central Statistical Office (GUS), Warsaw p. 2.

Kilter W (2011)., Bezpieczeństwo narodowe RP. Podstawowe kategorie, uwarunkowania, system [National security of the Republic of Poland. Basic categories, determinants, system], AON, Warsaw p. 168.

Leszczyński M. (2012), Wplyw demografii na poziom bezpieczeństwa społecznego [Impact of demography on social security levels], in: A. Skrabacz., S. Sulowski (eds.), Bezpieczeństwo społeczne. Pojęcie, uwarunkowania, wyzwania [Social security. Concept, determinants, challenges], Dom Wydawniczy ELIPSA, Warsaw, p. 183.

Malec J. (1986), Patologia społeczna jako zjawisko. Projekt definicji [Social pathology as a phenomenon. Definition proposal], Państwo i prawo, no. 4, p. 17.

Maslow A. (2006), Motywacja i osobowość [Motivation and Personality], PWN, Warsaw, p. 62.

Notatka informacyjna - Podstawowe informacje o rozwoju demograficznym Polski do 2014 r. [Information note - Basic information on the demographic development of Poland up to 2014] (2015), GUS, Warsaw, pp. 9-10.

Rocznik demograficzny 2020 [Demographic Yearbook 2020], GUS, Warsaw, p. 26-27.

Skrabacz A. (2012), Bezpieczeństwo spoleczne. Podstawy teoretyczne i praktyczne [Social Security. Theoretical and practical foundations], Dom Wydawniczy ELIPSA, Warsaw, pp. 9, 89.

Skrabacz A. (2012), Uwarunkowania tworzenia bezpieczeństwa spolecznego w XXI wieku [The conditions for establishing social security in the 21st century], in: A. Skrabacz, Sulowski S. (eds.), Bezpieczeństwo społeczne. Pojęcie, uwarunkowania, wyzwania [Social security. Concept, determinants, challenges], Dom Wydawniczy ELPISA, Warsaw, p. 53.

Stownik terminów z zakresu bezpieczeństwa narodowego [The glossary of terms in the field of national security](2002), AON, Warszawa 2002, p. 87.

Sytuacja demograficzna Polski do 2019 r. Migracje zagraniczne ludności w latach 2000-2019 [Demographic situation of Poland until 2019. International migration of population between 2000 and 2019](2020), GUS, Warsaw 2020, p. 220.

Uchwała Sejmu Rzeczypospolitej Polskiej z dnia 1 sierpnia 1997 r. - Karta Osób Niepetnosprawnych [Resolution of the Sejm of the Republic of Poland of 1 August 1997 - Charter of Disabled Persons], M.P. [Monitor Polski] of 1997 no. 50 it. 475 , Sec.1.

http://www.google.com/publicdata/explore?ds=d5bncppjof8f9_\&ctype=1\&strail=false\&nselm=h\&met_y=sp_pop_grow\&met_y=sp_ pop_grow [access date: 02.03.2021].

https://stat.gov.pl/obszary-tematyczne/rynek-pracy/bezrobocie-rejestrowane/stopa-bezrobocia-rejestrowanego-w-latach-1990-2020,4,1.html [access date: 26.02.2020].

https://www.worldometers.info/coronavirus/ [access date: 02.03.2021].

Jerzy TROCHA (born on 1 August 1990 in Płock) - Assistant professor at the Institute of Security Sciences at the Academy of Justice, specialist in the field of civil security in public and private sector enterprises. Graduate of doctoral studies at the Academy of Military Art. Author of over 20 scientific publications on national security. Specialises in the issues of crisis management, civil protection and public security.

ORCID ID: https://orcid.org/0000-0002-2561-4485

This work is licensed under the Creative Commons Attribution International License (CC BY).

http://creativecommons.org/licenses/by/4.0/ 